\title{
The lower Miocene flint conglomerate, Jylland, Denmark: a result of the Savian tectonic phase
}

\author{
Erik Skovbjerg Rasmussen ${ }^{1 *}$, Karen Dybkjær ${ }^{1}$ \\ ${ }^{1}$ Geological Survey of Denmark and Greenland (GEUS), Copenhagen, Denmark
}

\begin{abstract}
The early Miocene was an important period for the development of the eastern North Sea. Tectonism in North-West Europe resulted in uplift of the Scandinavian mountains, reactivation of salt structures, inversion of old graben structures and deposition of the most coarse-grained deposits in the Danish pre-Quaternary succession. Some of these deposits were later cemented into conglomerates. The deposits are common in the fluvial parts of the Billund Formation (Aquitanian) and the basal transgressive lag of the late Aquitanian - Burdigalian Klintinghoved Formation capping the Billund Formation. Questions remained as to the age of these deposits and what they infer about tectonic events in the region. This study reviews the geology of the flint-dominated conglomerates and presents the first dates for a sample of these unique deposits. We observe grain sizes up to $5 \mathrm{~cm}$ diameter. Palynological analyses place the sample as early Miocene. Some samples from the area have suggested a local source near active salt structures, associated with the uplift of the pre-Neogene sedimentary successions. We suggest that the common occurrences of flint clasts in the lower Miocene succession reveal significant erosion of Upper Cretaceous and Danian chalk, likely associated with the uplift of the Scandinavian lowlands during the Savian tectonic phase, early Miocene.
\end{abstract}

\section{Introduction}

The existence of a conglomerate dominated by flint in central and western Jylland, western Denmark, has been known for many years. Samples of it are commonly caught by rock dredging in the North Sea, particularly at Jyske Rev off the coast of Thyborøn (Fig. 1B). The conglomerate was described by $\varnothing$ dum (1968) as "et groft konglomerat [...] af ganske overvejende flintrullesten i en grundmasse af sandsten," translated as "a coarse-grained conglomerate [...] consisting mainly of flint gravel in a matrix of sandstone." He interpreted the conglomerate as having originated from an unknown 'Palaeogene' formation located in the Skagerrak area.

Extensive mapping of aquifers in Jylland during the past two decades has contributed to a wealth of information about the Neogene succession in Denmark. Detailed studies of outcrops, drilling and analysis of more than 50 boreholes, acquisition of high-resolution seismic data and the development of a solid biostratigraphic framework for the succession now exist (e.g. Dybkjær \& Rasmussen 2000, 2007; Dybkjær \& Piasecki 2010; Rasmussen et al. 2010).
*Correspondence: esr@geus.dk

Received: 03 Mar 2020

Accepted: 21 Aug 2020

Published: 02 Nov 2020

Keywords: biostratigraphy, flint conglomerate, North Sea, Miocene, tectonism

GEUS Bulletin is an open access, peerreviewed journal published by the Geological Survey of Denmark and Greenland (GEUS). This article is distributed under a CC-BY 4.0 licence, permitting free redistribution, and reproduction for any purpose, even commercial, provided proper citation of the original work. Author(s) retain copyright.

Edited by: Michael Bryld Wessel Fyhn (GEUS, Denmark)

Reviewed by: Henrik Friis (Aarhus University, Denmark) and one anonymous reviewer

Funding: See page 6

Competing interests: None declared

Additional files: None provided 

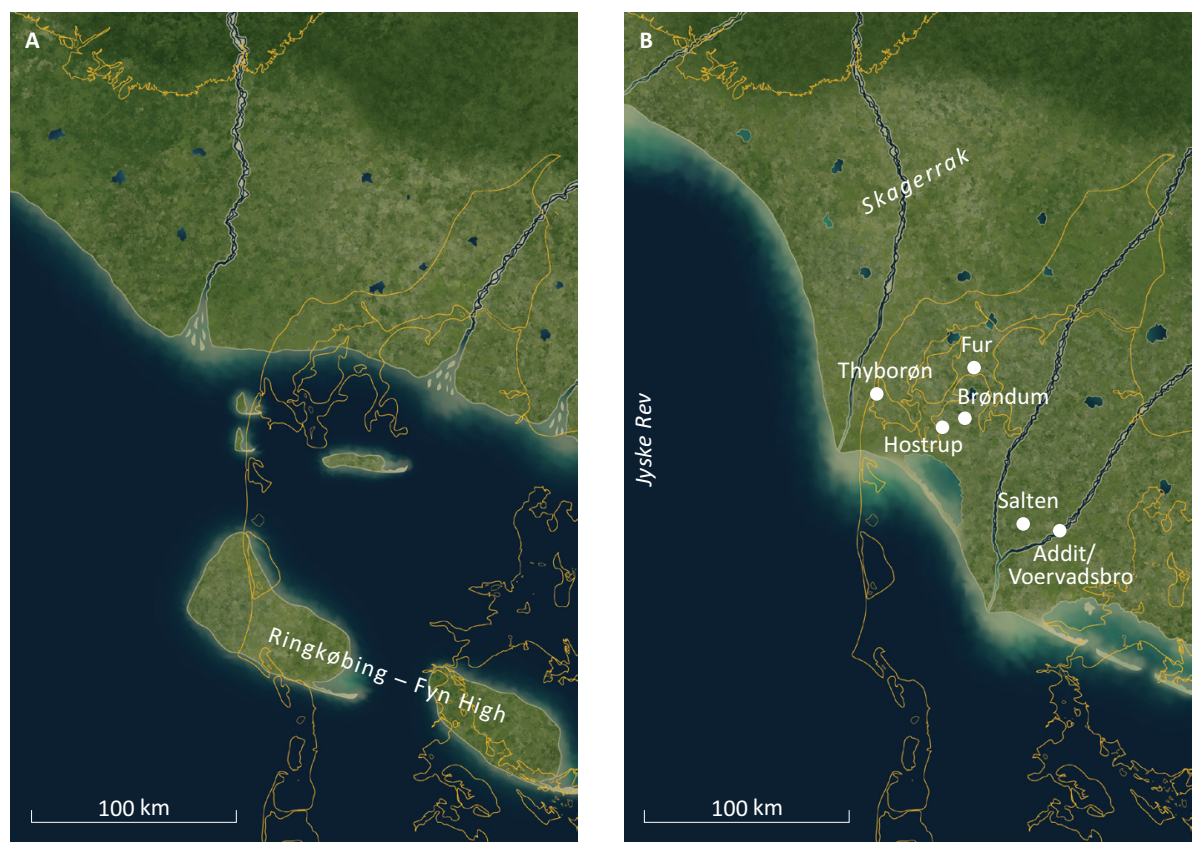

Fig. 1 Two palaeogeographic reconstructions of the early Miocene eastern North Sea. Approximate locations of the samples used in this study are shown. A: Early part of the Miocene transgression (c. $22.5 \mathrm{Ma}$ ). Parts of the Ringkøbing-Fyn High and topographic highs above salt diapirs formed islands in the Miocene sea. On the islands formed by salt diapirs, Cretaceous and Danian chalk was exposed and formed coastal cliffs. B: Progradation of the Billund delta-system during the early Miocene (c. $22 \mathrm{Ma}$ ). The quartz clasts of the flint conglomerate were transported to the area of west of Thyborøn by the western river system that had its outlet in the west of Jylland. Modified from Rasmussen et al. (2010).

These studies revealed a number of conglomerates, most of which, if not all, correlate with gravel layers in the region. The gravel layers formed during the deposition of the lower Miocene Billund Formation and the basal part (transgressive lag) of the succeeding Klintinghoved Formation. The transgressive lag of the Klintinghoved Formation, which is commonly cemented, is thought to be the source for these conglomerates found in the Quaternary succession in Jylland, Denmark.

In this study, we review the history of these conglomerates and present the first dates for a sample of the unique flint conglomerate first defined by $\varnothing$ dum (1968) from offshore Jylland, west Denmark. We relate these dates to the gravel layers from onshore Jylland. In doing so, we begin to unravel the geological significance of this conglomerate, which is a part of the most coarse-grained deposits of the Billund and Klintinghoved Formations in the Danish stratigraphic column.

\section{Geological setting}

By the end of the Early Permian, during the final phase of the formation of Pangea, the North Sea area was characterised by strong earthquake activity and volcanism, and many of the structural elements, including the Skagerrak Platform, the Sorgenfrei-Tornquist Zone, the Norwegian-Danish Basin and the Ringkøbing-Fyn High, were formed (Ziegler 1990). This period was succeeded by thermal subsidence, which resulted in the formation of a regional depression, the so-called North Permian Basin (Ziegler 1990). The basin was located just north of the palaeo-Equator, which formed optimal conditions for an extremely dry climate and a desert environment. During the Late Permian, this basin was flooded several times and evaporites were deposited. The dry climate continued during the Triassic and was characterised by desert environments with the deposition of thick alluvial successions along the southern margin of Scandinavia. By the end of the Triassic, a humid climate was established, and a regional transgression commenced. Marginal marine sedimentation dominated the Danish area in the latest Triassic and earliest Jurassic time, but continued transgression resulted in a fully marine depositional environment in the early Jurassic. The North Sea Basin and Scandinavia were strongly affected by mid-Jurassic updoming and succeeding rifting activity (e.g. Underhill \& Partington 1993; Andsbjerg et al. 2001; Andsbjerg \& Dybkjær 2003). In the aftermath of this tectonically active period, the basin underwent thermal subsidence during most of the Cretaceous. Consequently, the basin was filled with mudstone and chalk during the Cretaceous (Surlyk et al. 2013 and references therein). Chalk deposition culminated in the Late Cretaceous, where the influx of siliciclastic sediments to the basin was limited due to a very low relief of the hinterlands and a high global sea level. The relief of parts of southern Norway was in the order of c. $100 \mathrm{~m}$ (Sømme et al. 2019), and most of the Scandinavia was covered by marine chalk and mud deposits (Jarsve et al. 2014). Periodically, however, due to inversion tectonism (Alpine Orogen), local areas were uplifted at the margin of the Scandinavia, and smaller deltas prograded into the North Sea Basin (Erlström 1994). The overall marine depositional setting established in the Cretaceous continued during the Paleocene. However, the portion of Scandinavia facing the North Atlantic was exposed to uplift associated with the opening of the North Atlantic and a topography of more than $1000 \mathrm{~m}$ existed by the end of the Paleocene (Sømme et al. 2019). Uplift resumed in the late Eocene, 
and prograding wedges from Scandinavia formed in the North Sea Basin in the early Oligocene. By the end of the Oligocene and in the early Miocene, regional scale inversion tectonism occurred in Central Europe (Pharaoh et al. 2010 and references therein). This inversion also influenced the North Sea as seen in inversion of the Sole Pit axis and of the Central Graben (Rasmussen 2009; Green et al. 2017). Uplift of the southern Scandinavia is also indicated by significant sediment influx into the basin (Rasmussen 2004) and revealed by exhumation studies (e.g. Japsen et al. 2007). Consequently, most of the present-day Denmark became land during the early Miocene (Fig. 1; Rasmussen et al. 2010). Major reorganisation of the tectonic regime during the mid-Miocene resulted in flooding of the early Miocene deltas in the North Sea, and marine conditions were re-established. During the late Miocene, delta progradation from Scandinavia resumed both in the North Sea and in the northern North Atlantic.

\section{Materials and methods}

During numerous field campaigns in the past 20 years, 25 outcrops have been studied and logged by conventional facies analysis. In addition, a total of 50 boreholes across Jylland have been described for sediment texture. This resulted in the establishment of a new lithostratigraphy for the onshore Danish Miocene succession (Fig. 2; Rasmussen et al. 2010). A chronostratigraphic framework for the Miocene succession was established based on the studies of the dinoflagellate cyst (dinocyst) assemblages in more than 2000 sediment samples from both outcrops and boreholes (Dybkjær \& Piasecki 2010).

For this study, we conducted palynological (dinocyst) analyses on a sample of flint conglomerate from Jyske
Rev, offshore Jylland, west Denmark. The conglomerate contained a sea-urchin of the Late Cretaceous genus Galerites and both angular and rounded flint clasts. This piece is classed as 'danekræ' (DK 862; Fig. 1B), a Danish classification for the preservation of natural historical objects of unique scientific value.

In addition, several series of samples have previously been analysed from cemented sandstone from Brøndum gravel pit, onshore western Denmark and the succession comprising the flint-rich gravel layer from the cliff at Hostrup, north-west Jylland, and from fluvial, gravel-rich deposits from the Addit and Voervadsbro pits and the Salten section (Dybkjær and Piasecki 2010 and references therein; Fig. 1B).

The sediment samples were processed using standard palynological preparation methods, including treatment with $\mathrm{HCl}$ to dissolve calcareous matter and with HF to dissolve silicates. The acid treatment was followed by neutralisation with water, brief oxidation with $\mathrm{KOH}$ and sieving on $20 \mu \mathrm{m}$ nylon mesh. The organic residues, including the dinocysts, were then mounted on a glass slide using glycerin gel and studied using a normal light microscope.

In the following sections, we review the previously published understanding of the age and formation of the Miocene conglomerates, supplemented by our new observations and dates from sample DK 862.

\section{The Miocene conglomerates}

During the Oligocene-Miocene transition, a dramatic change occurred in the depositional environment in the eastern North Sea Basin. From a dominance of pelagic and hemipelagic fine-grained sedimentation that lasted from the Paleocene to the Oligocene (Heilmann-Clausen

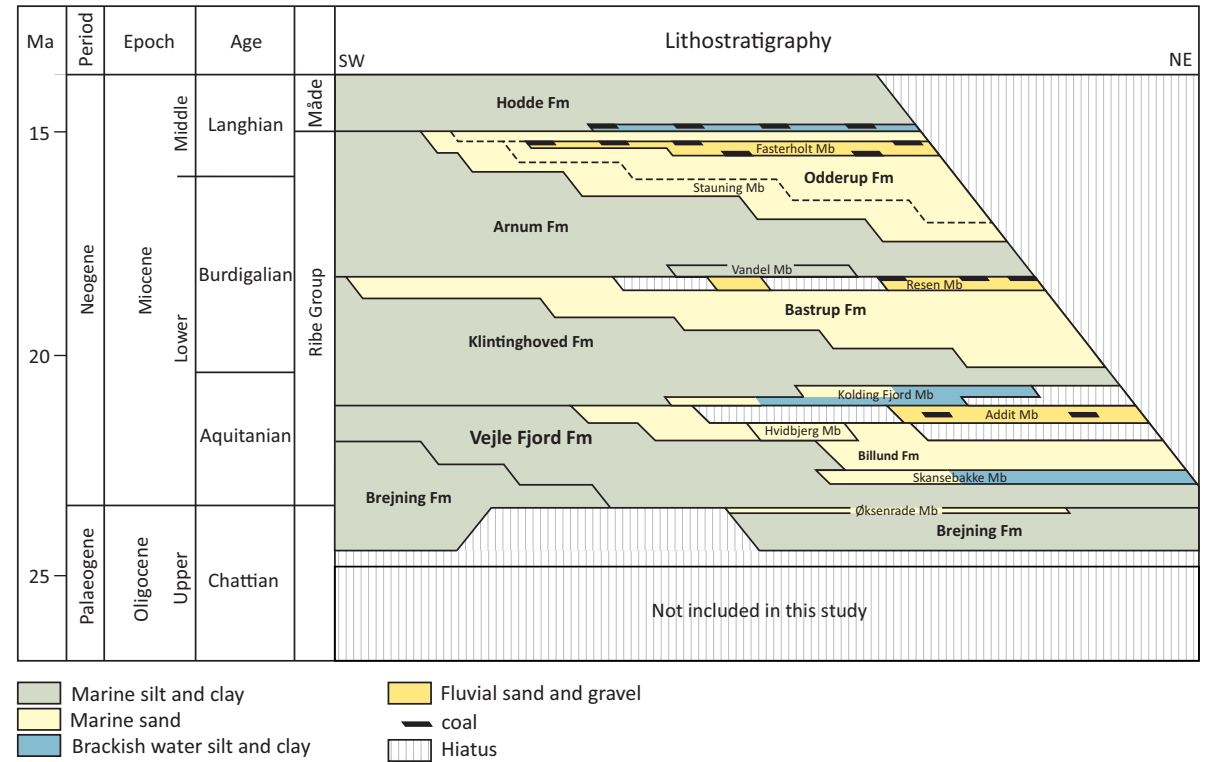

Fig. 2 Lower Miocene lithostratigraphy of Denmark. Note that the Billund (including the Addit Member) and Klintinghoved Formations form the lowermost part of the Lower Miocene. Modified from Rasmussen et al. (2010) 
et al. 1985; Nielsen et al. 2015), deposition of a vast sandand gravel-rich delta occurred in the early Miocene (Rasmussen et al. 2010). In this delta, gravel and cobbles were transported into the marine part of the North Sea Basin. The gravel clasts are composed of quartz, quartzites and flint, some of which originate as far away as Jotunheim in present-day Norway and areas in central Sweden (Olivarius et al. 2014). The gravel clasts studied here are up to $5 \mathrm{~cm}$ in diameter (Figs 3A, B and C). Some of the flint cobbles are rounded and show evidence of long transport (Fig. 3D), whereas flint clasts found in the north-western part of Denmark clearly indicate short transport distances, as indicated by the well-preserved sea urchins (Galerites) and angularity of some clasts (Figs $3 \mathrm{~A}$ and $\mathrm{B}$ ). It cannot be excluded that rounded flint clasts were also formed on beaches fringing local salt structures, but the coexistence of rounded flint clasts, rounded quartz and quartzites of the same grain size indicates that a larger source area, i.e. Scandinavia. As such, the wide geographical distribution of the rounded flint clasts points towards a regional source that is not restricted to local salt structures. Coarse-grained clasts are commonly found in channel thalweg deposits of the Addit Member of the Billund Formation (Fig. 2), along erosional boundaries within fluvial systems, or concentrated within a basal conglomerate of the Klintinghoved Formation that was formed during the early Miocene flooding of the Billund delta system.

All of the palynological samples studied here reveal an early Miocene age (Fig. 4). The danekræ DK 862 is dated to the early Aquitanian, earliest early Miocene, dinocyst zone Chiropteridium galea of Dybkjær and Piasecki (2010). The transgressive lag capping the Billund delta system is dated to the latest Aquitanian - earliest Burdigalian, early Miocene, dinocyst zone Thalassiphora pelagica of Dybkjær and Piasecki (2010). This places the conglomerate in the lower Miocene Billund and Klintinghoved Formations (Fig. 2).

\section{Depositional environment}

It is likely that the coarse-grained lower Miocene deposits were transported in fluvial systems, sourced from Scandinavia (present-day southern Norway and central Sweden). The catchment area covers c. 250000 km² (Olivarius et al. 2014), and during the earliest early Miocene, a predominance of braided river systems characterised the landscape across Jylland (Rasmussen 2014). The climate was warm and humid (Larsson et al. 2011). The river systems were perennial with channels up to $12 \mathrm{~m}$ deep and $800 \mathrm{~m}$ wide. The eastern portion of the Miocene North Sea was storm influenced, so the delta systems were wave dominated. The delta systems prograded into a shallow sea, c. $100 \mathrm{~m}$ deep (Fig. 1). Locally, islands were present in northern Jylland (Fig. 1A). These islands were formed by salt diapirism, similar to the present-day Helgoland, German North Sea, and exposed Paleocene clay, diatomite and Cretaceous and Danian chalk.

\section{Large-scale tectonism}

The abrupt change in the depositional setting, from deep marine clay to deltaic deposits at the OligoceneMiocene transition in the eastern North Sea, was caused by regional compression associated with Alpine tectonism in the Savian phase (Rasmussen 2004; Pharaoh et al. 2010). Regional inversion associated with this
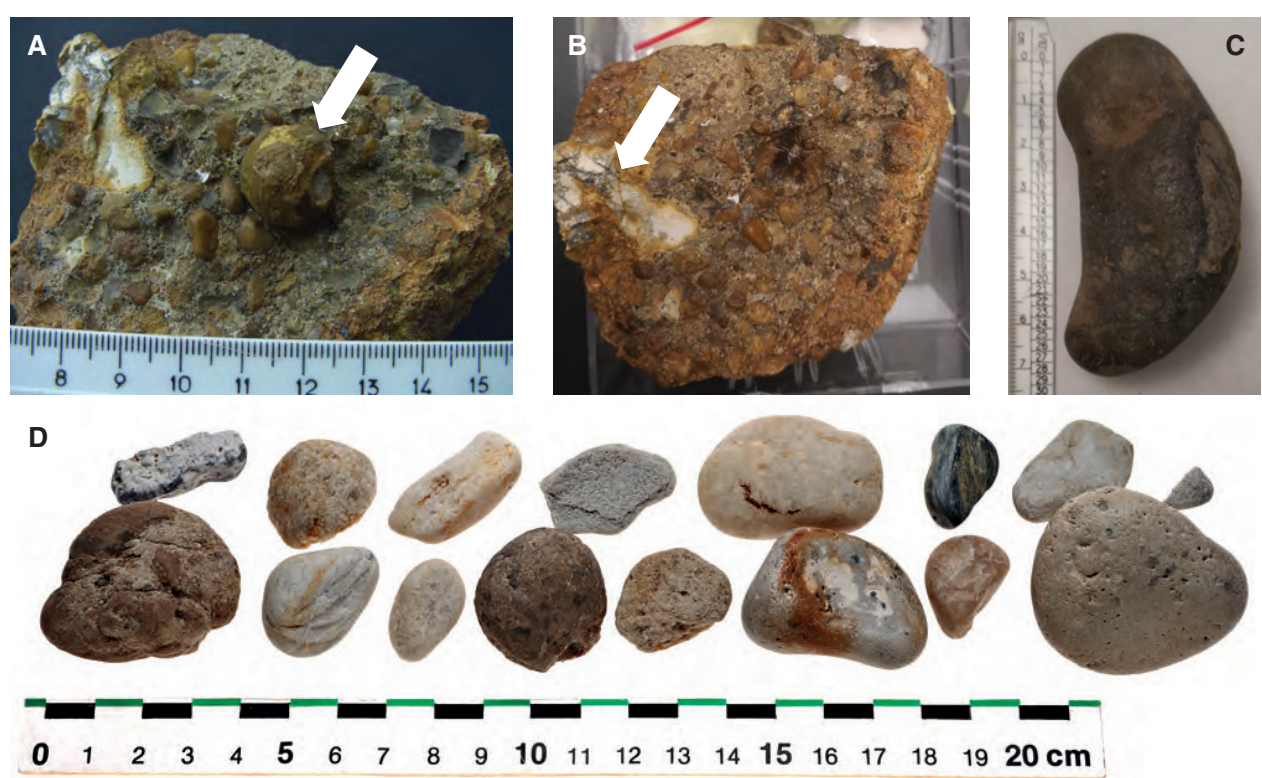

Fig. 3 Flint conglomerate (DK 862) and loose clasts found in the lower Miocene Billund and Klintinghoved Formations. A: Flint conglomerate with a well-preserved sea urchin (Galerites) of Late Cretaceous age, indicated by an arrow. B: Angular clast of flint c. $2 \mathrm{~cm}$ (arrow). C: Elongated flint clast from the fluvial Addit Member of the Billund Formation. D: Quartzites, quartz, rock fragments and flint found in the basal gravel lag of the Klintinghoved Formation. Note the diameter of the rounded clasts is up to $5 \mathrm{~cm}$ and $7 \mathrm{~cm}$. 

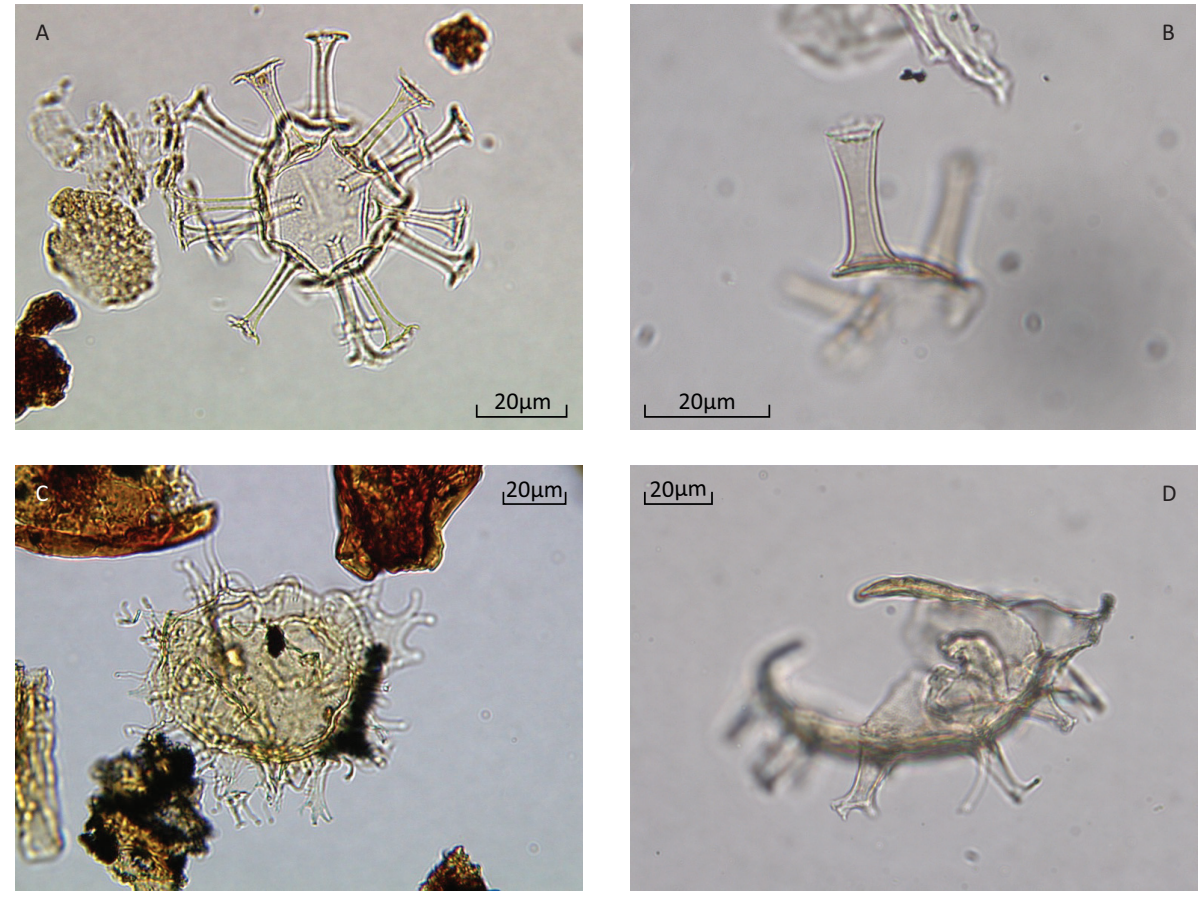

Fig. 4 Dinocysts from the Lower Miocene succession onshore Denmark (left) and the offshore flint conglomerate (DK 862; right). A: Well preserved, whole specimen of Homotryblium tenuispinosum from a nearby lower Miocene outcrop for comparison. B: $H$. tenuispinosum fragment from the flint conglomerate (DK 862). C: Well preserved, whole specimen of Chiropteridium galea from a nearby lower Miocene outcrop for comparison. D: C. galea fragment from the flint conglomerate (DK 862). phase in Central Europe resulted in the Weald and Sole Pit anticlines in the UK and up-doming of the Igor Ridge in the Danish North Sea (Vejbæk et al. 2006; Rasmussen 2009; Knox et al. 2010; Green et al. 2017). The formation of the salt structures, exposing chalk in the early Miocene, coincided with this regional inversion tectonism in North-West Europe. The sea urchins and angular flint clasts presented here, and those found around salt structures in northern Jylland, also place the formation of these structures during the earliest early Miocene. Therefore, it is likely that parts of the Norwegian-Danish Basin were also inverted during this compressional phase, similar to the Igor ridge in the Danish Central Graben and the Sole Pit and Weald Basin in the United Kingdom. However, due to later erosion, direct evidence was lost. The occurrence of Precambrian quartzite clasts, with a diameter of up to $5 \mathrm{~cm}$, reveals also that parts of Scandinavia were uplifted during the Savian phase. Clasts of that size can only be transported in river systems with high flow velocities and a gradient higher than river systems filling a tectonically quiescent basin. Although there has not been a quantification of the content of flint in the conglomerates and gravel layers, the common occurrence of flint indicates that a significant portion of the deposits originated from chalk that covered parts of present-day Norway and Sweden. Palaeorelief of southern Norway estimated by Sømme et al. (2019) reveals a very low topography during the Late Cretaceous, and given higher sea-level during the Cretaceous, most of southern Norway was probably submerged at that time (Jarsve et al. 2014).

\section{A unique conglomerate}

The conglomerate sample examined here and the associated gravel layers containing both flint, quartz and quartzite are unique in the pre-Quaternary succession of Denmark. Such mixed conglomerates or gravel deposits containing large clasts up to $5 \mathrm{~cm}$ in diameter do not occur at any other levels. Similarly, large clasts found within the basal part of the Hodde Formation (Koch 1989) consist solely of flint and are probably associated with local salt structures. The presence of quartzite clasts that have their origin in Scandinavia indicates long transport distances. This implies a high gradient and discharge of the river systems capable of transporting the clasts. In modern environments, such rivers are found in tectonically active areas. Low relief in southern Scandinavia during the Late Cretaceous permitted chalk and clay deposition here Jarsve et al. 2014). Some of this chalk was reworked during Cenozoic uplift, e.g. during the Paleocene and particularly in the early Miocene as indicated by the conglomerate described here. We infer that this part of the Miocene seems to have experienced significant uplift of the Scandinavian mountains and significant erosion of the Cretaceous deposits comprising mainly chalk with flint nodules, which, at that time, covered present-day southern Norway and central Sweden.

\section{Acknowledgements}

We would like to thank Jacob Lind Bendtsen and Stefan Sølberg for help drafting the figures. The lab-technicians Anette Ryge and Charlotte Olsen are thanked for the processing of the palynological samples. Henrik Friis and an anonymous reviewer are thanked for constructive comments on the manuscript. 


\section{Additional information}

\section{Funding}

This study was funded by internal funds at GEUS.

\section{Authors' contributions}

ESR: responsible for sedimentology and regional geology, drafted the main part of the paper. KD: conducted palynological analyses, drafted the palynological methods and text related to dating of the conglomerate.

\section{References}

Andsbjerg, J. et al. 2001: Divergent development of two neighbouring basins following the Jurassic North Sea doming event: the Danish Central Graben and the Norwegian-Danish Basin. In: Martinsen, O.J. \& Dreyer, T. (eds): Sedimentary environments offshore Norway Palaeozoic to recent. Norwegian Petroleum Society Special Publications 10, 175-197. https://doi.org/10.1016/s0928-8937(01)80013-8

Andsbjerg. J. \& Dybkjær, K. 2003: Sequence stratigraphy of the Jurassic of the Danish Central Graben. In: Ineson, J.R. \& Surlyk, F. (eds): The Jurassic of Denmark and Greenland. Geological Survey of Denmark and Greenland Bulletin 1, 265-300. https://doi.org/10.34194/geusb.v1.4675

Dybkjær, K. \& Piasecki, S. 2010: Neogene dinocyst zonation in the eastern North Sea Basin, Denmark. Review of Palaeobotany and Palynology 161, 1-29. https://doi.org/10.1016/j.revpalbo.2010.02.005

Dybkjær, K. \& Rasmussen, E.S. 2000: Palynological dating of the Vejle Fjord Formation (Chattian) and the lower part of the Arnum Formation (Aquitanian - lower Burdigalian), Lillebælt, Denmark. Bulletin of the Geological Society of Denmark 47, 87-103.

Dybkjær, K. \& Rasmussen, E.S. 2007: Organic-walled dinoflagellate cyst stratigraphy in an expanded Oligocene-Miocene boundary section in the eastern North Sea Basin (Frida-1 Well, Denmark) and correlation from basinal to marginal areas. Journal of Micropalaeontology 26, 1-17. https://doi.org/10.1144/jm.26.1.1

Erlström, M. 1994: Evolution of cretaceous sedimentation in scania. Lund Publication in Geology 122, 1-37.

Green, P.F., Duddy, I.R. \& Japsen, P. 2017: Multiple episodes of regional exhumation and inversion identified in the UK Southern North Sea based on integration of palaeothermal and palaeoburial indicators. Geological Society, London, Petroleum Geology Conference Series 8, 47-65. https://doi.org/10.1144/pgc8.21

Heilmann-Oausen, C., Nielsen, O.B. \& Gersner, P. 1985: Lithostratigraphy and depositional environments in the Upper Paleocene and Eocene of Denmark. Bulletin of the geological Society of Denmark 33, 287-323.

Japsen, P. et al. 2007: Mesozoic-Cenozoic exhumation events in the eastern North Sea Basin: a multi-disciplinary study based on palaeothermal, palaeoburial, stratigraphic and seismic data. Basin Research 19, 451-490. https://doi.org/10.1111/j.1365-2117.2007.00329.x

Jarsve, E.M. et al. 2014: Mesozoic and Cenozoic basin configuration in the North Sea. In: Martinus, A.W., et al. (eds): From depositional systems to sedimentary successions on the Norwegian Continental Margin, 417-452. International Association of Sedimentologists. https://doi. org/10.1002/9781118920435.ch15

Knox, R. et al. 2010: Cenozoic. In: Doornenbal, J.C. \& Stevenson, A.G. (eds): Petroleum Geological Atlas of the Southern Permian Basin Area, pp. 210-323. Houten: EAGE Publications b.v.

Koch, B.E. 1989: Geology of the Søby-Fasterholt area. Danmarks Geologiske Undersøgelse Series A 22, 171.
Larsson, L.M. et al. 2011: Miocene climate evolution of northern Europe: a palynological investigation from Denmark. Palaegeography, Palaeoclimatology, Palaeoecology 309, 161-175. https://doi.org/10.1016/j. palaeo.2011.05.003

Nielsen, O.B., Rasmussen, E.S. \& Thyberg, B. 2015: Distribution of clay minerals in the northern North Sea basin during the Paleogene and Neogene: a result of source-area geology and sorting processes. Journal of Sedimentary Research 85, 562-581. https://doi. org/10.2110/jsr.2015.40

Ødum, H. 1968: Flintkonglomeratet i Jylland. Tertiærformation og ledeblok. Meddelelser Dansk Geologisk Forening (Bulletin) 18, 1-24, +9 appendices, 4 plates.

Olivarius, M. et al. 2014: Provenance signal variations caused by facies and tectonics: zircon age and heavy mineral evidence from the Miocene sand in the north-eastern North Sea Basin. Marine and Petroleum Geology 49, 1-14. https://doi.org/10.1016/j.marpetgeo.2013.09.010

Pharaoh, T. et al. 2010: Tectonic evolution. In: Doornenbal, J. C. \& Stevenson. A. G (Eds.) Petroleum Geological Atlas of the Southern Permian Basin Area, 25-57. Houten: EAGE Publications b.v.

Rasmussen, E.S. 2004: The interplay between true eustatic sea-level changes, tectonics, and climatical changes: what is the dominating factor in sequence formation of the Upper Oligocene-Miocene succession in the eastern North Sea Basin, Denmark? Global and Planetary Change 41, 15-30. https://doi.org/10.1016/j.g/op/acha.2003.08.004

Rasmussen, E.S. 2009: Neogene inversion of the Central Graben and Ringkøbing-Fyn High, Denmark. Tectonics 465, 84-97. https://doi. org/10.1016/j.tecto.2008.10.025

Rasmussen, E.S. 2014: Development of an incised-valley fill under the influence of tectonism and glacio-eustatic sea-level change: valley morphology, fluvial style, and lithology. Journal of Sedimentary Research 84, 278-300. https://doi.org/10.2110/jsr.2014.24

Rasmussen, E.S. \& Dybkjær, K. 2005: Sequence stratigraphy of the Upper Oligocene - Lower Miocene of eastern Jylland, Denmark: role of structural relief and variable sediment supply in controlling sequence development. Sedimentology 52, 25-63. https://doi. org/10.1111/j.1365-3091.2004.00681.x

Rasmussen, E.S., Dybkjær, K. \& Piasecki, S. 2010: Lithostratigraphy of the upper Oligocene - Miocene succession in Denmark. Geological Survey of Denmark and Greenland Bulletin 22, 92. + 9 plates. https://doi. org/10.34194/geusb.v22.4733

Sømme, T.O. et al. 2019: Manifestation of tectonic and climatic perturbations deep-time stratigraphy - an example from the Paleocene succession offshore western Norway. Frontiers in Earth Science 7, 303. https://doi.org/10.3389/feart.2019.00303

Surlyk, F. et al. 2013: Upper Campanian - Maastrichtian holostratigraphy of the eastern Danish Basin. Cretaceous Research 46, 232-256. https://doi.org/10.1016/j.cretres.2013.08.006

Underhill, J.R. \& Partington, M.A. 1993: Jurassic thermal doming and deflation in the North Sea: implications of the sequence stratigraphic evidence. Geological Society (London) Petroleum Geology Conference Series 4, 337-345. https://doi.org/10.1144/0040337

Vejbæk, O.V. et al. 2006: Chalk depth structure maps, Central to Eastern North Sea, Denmark. Geological Survey of Denmark and Greenland Bulletin 13, 9-12. https://doi.org/10.34194/geusb.v13.4962

Ziegler, P.A. 1990: Geological Atlas of western and central Europe. 2nd Edition. The Hague: Shell Internationale Petroleum Maatschappij B.V., 239 pp. 